\title{
Primary coronary stenting for treatment of acute myocardial infarction
}

\author{
Nurhay Abdurahman, Teguh Santoso, Hanafi B. Trisnohadi, Mikail N.T. Wangge, Dasnan Ismail
}

\begin{abstract}
Abstrak
Terapi trombolitik merupakan intervensi farmakologik terpenting pada infark akut, karena dengan memperbaiki aliran darah pada pembuluh infark yang tersumbat, terapi ini terbukti dapat melindungi jaringan otot miokard yang masih hidup, memperbaiki faal ventrikel kiri dan menurunkan angka kematian. Akan tetapi terapi cara ini hanya melarutkan bekuan darah dan tidak berpengaruh terhadap kerak aterosklerotik yang ada. Alternatif lain adalah intervensi mekanik dengan melakukan angioplasti koroner. Walaupun demikian penutupan kembali pembuluh darah serta restenosis tetap merupakan masalah. Dilaporkan pengalaman pemasangan stent intrakoroner pada 6 penderita. Angka keberhasilan 100\% tanpa disertai kematian, reinfark dan iskemia berulang. Pada pemantauan jangka pendek-sedang tidak terjadi penyulit dan revaskularisasi pembuluh yang diberi stent tidak diperlukan. Penyelidikan lebih jauh masih diperlukan untuk membuktikan keamanan dan manfaat cara terapi ini.
\end{abstract}

\begin{abstract}
The use of intravenous thrombolytic therapy has emerged as one of the most important pharmacological intervention in acute myocardial infarction, since by restoring blood flow in the occluded infarct related artery, it may preserve viable myocardial tissue, protect left ventricular function and reduce mortality. However, such approach only aims to dissolve the acute coronary thrombus and leave the underlying atherosclerotic plaque untreated. Another alternative is mechanical intervention by means of primary coronary angioplasty (primary PTCA). However, vessel reocclusion and late restenosis after successful PTCA remain a problem. We reported our initial experience with primary coronary stenting in 6 patients. Success rate was $100 \%$ with no death, reinfarction and recurrent ischemia. At short-medium follow-up there were no adverse major cardiac events and target vessel revascularization was not required. Further studies are required to prove the safety and feasibility of this treatment strategy.
\end{abstract}

Keywords : Acute myocardial infarction, angioplasty, stenting

\section{INTRODUCTION}

The understanding that a myocardial infarction is usually caused by an acute thrombotic obstruction of a coronary artery has led to a major change in tha approach of this disease. ${ }^{1}$ The use of intravenous thrombolytic therapy has emerged as one of the most important pharmacological interventions that is aimed at rapid restoration of blood flow in the occluded artery. Very early restoration of blood flow to the jeopardized myocardium tissue, protect left ventricular function and redure mortality. ${ }^{2}$ The most important conceptual deficit of thrombolytic therapy is that such approach only aims to dissolve the acute coronary thrombus and leave the underlying atherosclerotic plaque untreated. As an alternative to improve on this deficiency is mechanical intervention by means of

Division of Cardiology, Department of Internal Medicine, University of Indonesia Faculty of Medicine/Dr. Cipto Mangunkusumo Hospital, Jakarta, Indonesia primary coronary angioplasty (primary PTCA). ${ }^{3-5}$ However, vessel reocclusion after primary PTCA occurs in 5 to $10 \%$ of patients prior to discharge and late restenosis after successful PTCA remains is as high as $37-49 \% ., 6,7-10$

Coronary stenting is of established value to improve angiographic and clinical outcomes of PTCA and it may reduce in short lesions located in larger, native coronary arteries. ${ }^{11,12}$ Stenting is also beneficial in emergency treatment of acute or threatened closure complicating PTCA and is also of value in selected high risk lesions and with a suboptimal result after PTCA. $^{13}$

Coronary stent placement, however, has traditionally been avoided in thrombus related settings, such as acute myocardial infarction. Subacute stent thrombosis has been reported to be more common in this situation. ${ }^{14.15}$ However, better stent implantation techniques and antiplatelet strategies have allowed a dramatic reduction in the rates of subacute stent oc- 
clusion, permitting consideration of stenting in the setting of thrombus. ${ }^{16-18}$ Thus, the original taboo of stent implantation during acute myocardial infarction has been reconsidered.

In this paper, we describe our preliminary experience of primary coronary stenting in 6 patients with acute myocardial infarction.

\section{MATERIALS AND METHODS}

\section{Patients}

The study population consisted of those patients hospitalized because of acute myocardial infarction of less than 6 hours and who underwent primary PTCA followed by stenting (primary stenting) in the infarct related artery. Patients were excluded only if they had absolute contraindications to heparin, aspirin or ticlopidine, such as hemorrhagic diathesis, active bleeding, active peptic ulcer, recent stroke, known allergy or thrombocytopenia.

\section{Study Protocol}

All patients were pretreated with $160 \mathrm{mg}$ aspirin, 250 to $500 \mathrm{mg}$ of ticlopidine and intravenous heparin infusion. After obtaining written informed consent, patients were then transferred to the catheterization laboratory. Low osmolar, ionic contrast medium ("Hexabrix") was used to minimize the risk of thromboembolic complications. Coronary angiography was performed initially to the non-infarct related vessel then to the infarct related artery.

Before PTCA, $150 \mathrm{U} / \mathrm{kg}$ body weight heparin was given and if required, additional $2500 \mathrm{U}$ heparin every hour was administered to maintain an activated clotting time of $>350 \mathrm{~s}$. PTCA was performed using over the wire monorail ballons. After restoration of flow, the lesion was assessed for stent eligibility. The presence of thrombus was not considered as a contraindication for stenting, however, stenting was deferred if a large amount of thrombus burden present after PTCA. After stent deployment, high pressure dilatation was applied (> 12 atm). Persistent angiographic filling defect suggesting thrombus was treated with additional PTCA. Persistent dissection was treated with additional stent. All significant lesions (> 70\% stenosis) proximal and distal to infarct related lesion were dilated and if necessary also stented to obtain a good flow. None of the patient received abcixima ("Reopro").
After the procedure, heparin infusion was immediately discontinued. The sheaths were removed when the ACT fell below 170 s, usually approximately 4 to 6 hours later. Heparin infusion was restarted one hour after sheath removal. All patients were treated with oral aspirin (160 mg.day, indefinitely, ticlopidine (250 $\mathrm{mg}$ twice/daily for one month). No patients received oral anticoagulation. Other medications were used according to the clinical indication.

\section{RESULTS}

Of the 6 patients, 5 were men and one was woman. Their ages ranged from 32 to 77 years old (mean age 52 years). Hypertension was found in 2 patients, diabetes mellitus in one patient, cigarette smoking in 3 patients, prior myocardial infarction in none of the patients, prior PTCA in one patient, prior coronary artery bypass grafting in one patient. The mean time from symptom onset to arrival in the catheterization laboratory was 4.8 hours (range 3 to 12 hours).

ECG infarct location was anterior in 3 patients and inferior in 3 patients. None of the patients had non-Q wave infarction. On admission, 4 patients were in Killip Class I, two were in Killip Class II.

One patient (RMK) had been treated with alteplase ("Actylase") prior to the PTCA/stenting. However, he had recurrent severe chest pain associated with reappearance of marked ST elevation in the inferior leads, suggesting vessel reocclusion. Since he was still in the time window of less than 6 hours after onset of myocardial infarction, this patient was included in this series. PTCA ("rescue PTCA") and stenting of this patient was performed via the right radial artery. On angiogram the right coronary artery was completely occluded in the proximal segment. After recanalization, he developed ventricular fibrillation, which was easily reverted with DC shock. Coronary stent was successfully implanted and the patient was discharged asymptomatic on the third day.

Another patient (JB), who had prior unsuccessful PTCA and twice unsuccessful bypass surgery performed overseas, was admitted one hour after onset of an acute inferior wall infarction. He developed ventricular fibrillation and apnea a few minutes after giving consent to undergo primary PTCA/stenting. He was intubated and defibrillated and arterial as well as venous sheaths were inserted in the ICCU. He was put on ventilator throughout the PTCA/stenting procedure. This distal right coronary artery was completely occluded by thrombus just before the crux. After initial 
dilatation, a multilink stent was nicely placed in the culprit lesion. Kissing balloon technique was applied to open up both the left ventricular branch and the right posterior descending artery. Further clinical course was uneventful and he was discharged on the sixth day.

The clinical and angiographic characteristics of the other patients are presented in Tables 1 and 2. types of stents used were as follows: Multilink stent 3, Jo stent 2, NIR stent one, Crown stent one, half Palmaz-Schatz stent one.

There were no major in-hospital adverse cardiac events, including acute or subacute stent thrombosis, re-infarction, emergency bypass surgery, or death. The mean hospital stay ranged from 3 to 8 days. All patients were asymptomatic on clinical follow up ranging from

Table 1. Clinical characterictics of patients

\begin{tabular}{|c|c|c|c|c|c|c|}
\hline Patient & B & JOK & SG & $\mathrm{JB}$ & RMK & LTC \\
\hline Age & 77 & 32 & 52 & 54 & 44 & 53 \\
\hline $\mathrm{M} / \mathrm{F}$ & $F$ & M & M & $\mathrm{M}$ & M & $\mathrm{M}$ \\
\hline Hypertension & Yes & No & No & No & No & Yes \\
\hline Diabetes mellitus & Yes & No & No & No & No & No \\
\hline Dyslipidemia & Yes & Yes & Yes & Yes & Yes & Yes \\
\hline Smoking & No & Yes & Yes & No & No & Yes \\
\hline Prior MI & No & No & No & No & No & No \\
\hline Prior PTCA & No & No & No & Yes & No & No \\
\hline Prior CABG & No & No & No & Yes & No & No \\
\hline ECG infarct location & Ant. & Ant. & Inf. & Inf. & Inf. & Ant. \\
\hline Killip Class & I & II & I & II & I & I \\
\hline Time from onset to cath-lab (hrs.) & 4 & 3 & 12 & 2 & 3 & 5 \\
\hline
\end{tabular}

Abbreviations: Ant. anterior, CABG coronary artery bypass grafting, F female, hrs. hours, Inf. inferior, $M$ male, MI mycardial infarction

On angiography, infarct related distribution was the left anterior descending coronary artery in 3 patients, the right coronary artery in 3 patients and none in the left circumflex artery. Infarct artery lesion location was in the proximal segment in 3 patients, the mid segment in 2 patients and the distal segment in one patient. The infarct related artery was completely occluded in all patients.

Stents were successfully delivered to the lesion and deployed in all patients. All patients received only the stent, except one patient who required 3 stent. The one to more than 24 months. Two patients who had multivessel disease underwent repeat PTCA/stenting in another vessels.

\section{DISCUSSION}

Although after intravenous thrombolytic therapy in acute myocardial infarction the underlying atherosclerotic plaque remains untreated, it has been shown to prolong survival and preserve left ventricular function. However, there are important deficiencies. Only $33 \%$ of acute infarction patients receive throm-

Table 2. Angiographic characteristics of patients

\begin{tabular}{lllllll}
\hline Patient & B & KOK & SG & JB & RMK & LTC \\
\hline Extent of CAD & SVD & DVD & SVD & TVD & LM, TVD & SVD \\
Infarct related artery & LAD & LAD & RCA & RCA & RCA & LAD \\
Lesion location & Mid & Prox & Mid & Distal & Prox & Prox \\
No. of stent & 1 & 3 & 1 & 1 & 1 & 1 \\
Type of stent & NIR & Jo, & Crown & ML & Jo & ML \\
& & PS, MS & & & & \\
\hline
\end{tabular}

Abbreviations: CAD coronary artery disease, DVD double vessel disease, LAD left anterior descending coronary, LM left main, RCA right coronary artery, Prox. proximal, SVD single vessel disease, TVD triple vessel disease 
bolytic therapy. The median time to reperfusion is 45 minutes and there is no clinical markers to accurately predict reperfusion. twenty percent of infarct related vessels remain occluded and $45 \%$ still have impaired $(\mathrm{TIMI} \leq 2)$ flow. Besides, recurrent ischemia occurs in $15-30 \%$ and intracranial bleeding in $0.5-1.5 \% .{ }^{19}$

To improve on these deficiencies, primary PTCA has been advocated. Compared to thrombolysis, this strategy has the following advantages: (1) usefulness in thrombolytic-ineligible patients, (2) possibility for immediate definition of coronary anatomy, 93) usefulness for early risk stratification, (4) it results in better acute arterial patency and TIMI 3 flow compared to lytics $(95-99 \%$ vs $70-80 \%)$. (5) It is associated with less reocclusion, recurrent ischemia, reinfarction, and therefore further improves survival, especially in high risk patients. (6) It is associated with less reperfusion injury, cardiogenic chosk and myocardial rupture. (7) It has a lower risk of intracranial hemorrhage. (8) The length of hospital stay is shorter, and (9) in the USA and Europe the cost is similar. ${ }^{16}$ No studies had been done to assess the comparative cost of primary PTCA vs thrombolytic therapy in Asian countries.

Despite all these advantages, primary PTCA is also beyond perfection. After successful PTCA, recurrent ischemia still occurs in $10-15 \%$ of patients, which results in hemodynamic and arrhythmic complications, necessitates repeat catheterizations and revascularization procedures, prolongs hospital stay and increases costs. ${ }^{3,4,8,9}$ Reinfarction develops in 3-5\% of patients before hospital discharge and infarct-related artery reocclusion occurs in $5-10 \% .^{3,10}$ Late angiographic restenosis has been documented in $37-49 \%$ of patients, of whom $9-14 \%$ had late infarct- related artery reocclusion. ${ }^{6,10}$ Within 6 months after discharge, approximately $20 \%$ of patients would still require repeat PTCA or bypass surgery. ${ }^{3,6}$

Although concern has been appropriately expressed that stenting during the acute phase of myocardial may increase the risk of stent thrombosis, with better stent implantation technique and adequate antiplatelet therapy this has been demonstrated not to be the case. $^{20-22}$ Our limited experience also showed that primary stenting strategy is safe and feasible. With the routine application of high pressure implantation technique and anticoagulation regimen of aspirin and ticlopidine, we did not encounter a single case of acute or subacute thrombosis, or recurrent ischemia. Ventricular fibrillation, occuring in one patient with right coronary artery occlusion, is due to reperfussion and was therefore easy to manage. Although we did not do repeat angiography, all patients were asymptomatic on short-to-medium follow-up. In two patients, who underwent repeat PTCA/stenting to treat another stenotic lesion in another artery, their infarct related arteries were still patent.

Since stenting is technically more demanding than PTCA, meticulous attention has to be paid for to achieve a good result. Stents must not be underdeployed and hence high pressure inflation is mandatory. Stenting would allow one to deal with untreated dissection and residual stenosis. These two important limitations of primary PTCA have been demonstrated to be major predictors of recurrent ischemia and infarct related artery occlusion. ${ }^{23,24}$ The establishment by a stent of a wide lumen channel with a brisk antegrade flow and no dissection planes may facilitate natural clot resolution by endogenous fibrinolysis. Reinfarction and late infarct related artery restenosis after stenting may therefore be less common than after primary PTCA.

Economic and patient concerns about prolonged bed rest, anticoagulation and length of stay with primary stenting may not be as relevant as their hospital stay will be much shorter (3-7 days) and repeat revascularization because of recurrence may be less required.

Although large scale, randomized, multicenter trials are mandatory to establish the role of primary stenting in acute myocardial infarction, several small-medium scale studies reported impressive short-to-medium term results. ${ }^{25-30}$ In the future, with improved operator technique, new stent designs (i.e. stents coated with thromboresistant materials such as heparin or phosporylcholine), and the possible adjunctive use of parenteral, local or stent bonded glycoprotein IIb/IIIa inhibitors, the safety profile of primary stenting may be further enhanced. ${ }^{3 \mathrm{C}-35}$

\section{REFERENCES}

1. DeWood MA, Spores J, Notske R, et al. Prevalence of total coronary occlusion during early hours of transmural myocardial infarction. N Engl J Med 1980;303:897-902.

2. Yusuf $S$, Collins $R$, Peto $R$, et al. Intravenous and intracoronary fibrinolytic therapy in acute myocardial infarction: overview of results on mortality, reinfarction and side effects from 33 randomized controlled trials. Eur Heart J 1995;6:556-85.

3. Grines CL, Browne KF, Marco, J, et al. A comparison of immediate angioplasty with thrombolytic therapy for acute myocardial infarction. N Engl J Med 1993;382:673-9.

4. Zilstra F, De Boer MJ, Hoorntje JCA, et al. Comparison of immediate coronary angioplasty with intravenous strep- 
tokinase in acute myocardial infarction. $\mathrm{N}$ Engl $\mathrm{J}$ Med 1993;328:680-4.

5. The GUSTO-2b angioplasti substudy investigators. A clinical trial comparing primary coronary angioplasty with tissue plasminogen activator for myocardial infarction. N Engl J Med 1997;336:1621- 8.

6. Brodie BR, Grines CL, Ivanhoe R, et al. Six-month clinical and angiographic follow-up after direct angioplasty for acute myocardial infarction. Circulation 1994;90:156-62.

7. Nunn C, O'Neill W, Rothbaum D, et al. Primary angioplasty for acute myocardial infarction improves long term survival: PAMI-I follow-up. J Am Coll Cardiol 1996;27:153A.

8. Stone GW, Grines CL, Browne KF, et al. Predictors of in-hospital and 6 months follow-up after acute myocardial infarction in the reperfusion era: the primary angioplastu in myocardial infarction (PAMI) trial. J Am Coll Cardiol 1995;25:370-7

9. Michels KB, Yusuf S. Does PTCA in acute myocardial infarction affect mortality and reinfarction rates? A quantitative (meta- analysis) of the randomized trials. Circulation 1995;91:476-85.

10. Nakagawa $Y$, Iwasaki $Y$, Kimura $T$, et al. Serial angiographic follow-up after successful direct for acute myocardial infarction. Am J Cardiol 1996;78:980-4.

11. Fischman DL, Leon MD, Baim DS, et al. A randomized comparison of coronary-stent placement and ballon angioplasty in patients with coronary artery disease. $\mathrm{N}$ Engl J Med 1994;331:496-501.

12. Serruys PW, De Jaegere, Kiemineij F, et al. A comparison of balloon expandable stent implantation with ballooon angioplasty in patients with coronary artery disease. $\mathrm{N}$ Engl J Med 1994;331:489-95.

13. ACC Expert Consensus Document. Coronary artery stents. J Am Coll Cardiol 1996;782-94.

14. Agrawal SK, Ho DSW, Lio MW, et al. Predictors of thrombotic complications after placement of a flexible coronary stent. Am J Cardiol 1994;1216-9.

15. Nath FC, Muller DWM, Ellis SB, et al. Thrombosis of a flexible coil coronary stent: frequency predictors and clinical outcome. J Am Coll Cardiol 1993;21:622-7.

16. Colombo A, Hall $P$, Nakamura $S$, et al. Intracoronary stenting without anticoagulation accomplished with intravascular ultrasound guidance. Circulation 1995;91:1676-88.

17. Morice MC, Zemour G, Benvensite E, et al. Intracoronary stenting without coumadin: one month results of French multicenter study. Cathet Cardiovasc Diagn 1995;35:1-7.

18. Schomig A, Neumann FJ, Kastrati A, et al. A randomized comparison of antiplatelet and anticoagulation therapy after placement of coronary artery stents. N Engl J Med 1996;334:1084-9.

19. Grines C, Stone GW, O'Neil WW. PTCA in unstable syndromes. In: Freed M, grines C, Safian RD (eds): The new manual of interventional cardiology. Physician' Press, Birmingham, Michigan, Second ed., 1996, pp.107-54

20. LeFevre T, Morice MC, Karrilon G, et al. Coronary stenting during acute myocardial infarction. results from the stent without coumadin Frenc registry (abstr). J Am Coll Cardiol 1996;27:69A.

21. Garcia-Cantu E, Spaulding C, Corcos T, et al. Stent implantation in acute myocardial infarction. Am $\mathrm{J}$ Cardiol $1996 ; 77: 451-4$
22. Rodriguez AE, Fernandez M, Santaera $\mathrm{O}$, et al. Coronary stenting in patients undergoing percutaneous transluminal coronary angioplasty during acute myocardial infarction. Am J Cardiol 1996;77:685-9.

23. O'Keefe JH, Rutherford BD, McConahay DR, et al. Early and late results of coronary angioplasty without antecedent thrombolytic therapy for acute myocardial infarction. Am J Cardiol 1989;64:1221-30.

24. Benzully KH, O'Neil WW, Brodie B, et al. Predictors of maintained infarct artery patency after primary angioplasty in high risk patients in PAMI-2 (abstr). J Am Coll Cardiol 1996;27 Suppl A: 279A.

25. Nishida $Y$, Nokana $H$, Ueda $K$, et al. In-hospital outcome of primary stenting of acute myocardial infarction using Wiktor coil stent: Results of a multicenter randomized PRISAM study (abstr). Circulation, 1997;96 Suppl: 1-397.

26. Stone GW, Brodie BR, Griffin JJ, et al. Improved short term outcomes of primary stenting compared to primary angioplasty in acute myocardial infarction: The PAMI Stent Pilot Trial (abstr). Circulation 1997, 96 Suppl:I-594.

27. Saito S, Hosokawa G. Primary Palmaz-Schatz stent implantation for acute myocardial infarction: the final results of the Japanese PASTA (Primary Angioplasty vs Stent Implantation in AMI in Japan) trial (abstr). Circulation 1997, 96 Suppl : I-595.

28. Serruys PW, Garcia-Fernandez E, Kiemineij F, et al. Stenting in acute MI: A pilot study as preamble to a randomized trial comparing balloon angioplasty and stenting (abstr). Circulation 1997, 96 Suppl: I-326.

29. Suryapranata H, Hoorntje JCA, de Boer, et al. Randomized comparison of primary stenting with primary balloon angioplasty in acute myocardial infarction (abstr). Circulation 1997;96 Suppl:I-327.

30. Antoniucci D, Santoro GM, Bolognese L, et al. A prospective randomized trial of elective stenting in acute myocardial infarction - preliminary results of the FRESCO study (Florence Randomized Elective Stenting in Acute Coronary Occlusion) (abstr). Circulation 1997;96 Suppl: I-327.

31. Rogers C, Edelman ER, Endovascular stent design dictates experimental restenosis and thrombosis. Circulation 1995;91:2995- 3001.

32. Serruys PW, Emanuelsson HU, van der Griessen W, et al. Heparin-coated Palmaz-Schatz stents in human coronary arteries. Circulation 1996;913:412-22.

33. Grines CL, Morice MC, Mattos L, et al. A prospective, multicenter trial using the JJIS heparin coated stent for primary reperfusion of acute myocardial infarction (abstr). $\mathrm{J}$ Am Coll Cardiol 1997;29 Suppl A:389A.

34. The EPIC Investigators. Use of a monoclonal antibody directed against the platelet glycoprotein IIb/IIIa receptor in high risk coronary angioplasty. N Engl J Med 1994;330:95661.

35. Aggarwal RK, Ireland DS, Azrin MA, et al. Antithrombotic potential of polymercoated stents eluting platelet glycoprotein IIb/AAa receptor antibody. Circulation 1996;94:3311-7. 